\title{
Proximate Composition and Amino Acid Analysis of Defatted Tectona Grandis Seed Meal
}

\author{
Oyewusi, P.A., Onipede,A.E. and Babalola, O.O. \\ Federal Polytechnic, Science Technology Department, P.M.B. 5351, Ado-Ekiti, Ekiti-State, Nigeria.
}

\begin{abstract}
Teak is more considered as a major constituent in many of the traditional medicines. The proximate composition and amino acid analysis was carried out on deffated Tectona grandis seed meal. The proximate composition showed the following values; protein $42.0 \%$, ash $7.00 \%$, CHO $41.5 \%$, crude fibre $3.30 \%$, crude fat $1.00 \%$ and moisture content $5.20 \%$. The amino acid content showed that glutamate and aspatate have the highest concentrations with 23.6 and $12.2 \mathrm{~g} / 100 \mathrm{~g}$ respectively while the lowest concentrations were recorded for tryptophan and methionine with $0.806 \mathrm{~g} / 100 \mathrm{~g}$ and $0.889 \mathrm{~g} / 100 \mathrm{~g}$ respectively. Protein content of the seed meal was found to be acidic as total acidic amino acid (TAAA) is more than total basic amino acid (TBAA).
\end{abstract}

\section{Introduction}

The use of medicinal plants is the basis for traditional medicine system in many countries including Nigeria. These include various types of plants that have medicinal activities. They have rich resources of ingredients which can be used in drug development and synthesis. Some of the plants are considered as important source of nutrition and therefore recommended for their therapeutic values. In the recent times, "Altenative Medicine" or traditional medicine is now becoming more popular by focusing on the idea of using the plants for medicinal purposes (Singh et al., 1996). Tectona grandis (Teak) is one of such many plants that have been trusted and tested to belong to the group of medicinal plants.

(Tectona grandis) is a tropical hardwood species placed in the family Lamiaceae. It is a large, deciduous tree that occurs in mixed hardwood forests. It has small, fragrant white flowers and papery leaves that are often hairy on the lower surface. It is one of three species in the genus Tectona (Khera, 2007). The other two species, T. hamiltoniana and T. philippinensis, are endemics with relatively small native distributions in Myanmar and the Philippines, respectively. It can also be found in a variety of habitats and climatic conditions from arid areas with only $500 \mathrm{~mm}$ of rain per year to very moist forests with up to $5,000 \mathrm{~mm}$ of rain per year.

The whole plant has been reported to be medicinally important and many reports have been claimed to cure many diseases (Shruthi et al., 2012). The different extracts from various parts of teak shows expectorant, anti-inflammatory, anthelmintic properties ( Shruthi et al., 2012; Francisco et al., 2008). Traditionally, teak is used against bronchitis, biliousness, hyperacidity, diabetes, leprosy, astringent, and helmintiasis (Guptha and Singh, 2004; Goswami et al., 2010). In traditional medicine, a wood powder paste has been used against bilious headache and swellings (Khera and Bhargava, 2013). They are also used to treat swellings (Khera, 2007). According to ayurveda, the teak wood is acrid, cooling, laxative, sedative to gravid uterus and useful in treatment of piles, leucoderma and dysentery (Nayeem and Karvekar, 2010). It allays thirst and possesses anthelmintic and expectorant properties (Nayeem and Karvekar, 2010). T. grandis leaf extract are widely used in the folklore for the treatment of various kinds of wounds, especially burn wounds (Aboaba et al., 2013)

The fruit is a drupe with four chambers; round, hard and woody, enclosed in an inflated bladder like covering; pale green at first then brown at maturity. Each fruit contains 0 to 4 seeds. Seeds are oblong, brown, enclosed in bony endocarp (Khera and Bhargava, 2013). The seeds are traditionally acclaimed as tonic in the Indian system of medicine (Goel et al., 1987) and have been reported to be traditional acclaimed as hair tonic for growth in the Indian system of medicine (Jaybhaye et al., 2010).

A lot of work had been carried out on different parts of the plant but there is little information on the amino acid composition of the seed which is expected to point out the nutrition activities of the seed. The present work focuses of the proximate and amino acid composition of the defatted seeds of Tectona grandis.

\section{Materials and Methods}

Seeds were collected from the Federal Polytechnic, Ado Ekiti, Nigeria. The seeds were handpicked from the ground within the sampling point under the tree. They were cleaned and separated from sand, pebbles and other dirty materials. The seeds were cracked and separated from the endocarp. The resultant kernels were first sun dried and later oven dried at $60^{\circ} \mathrm{C}$ until samples were completely dried. Dried seeds were then milled with laboratory blender and kept in air tight plastic container. $5 \mathrm{~g}$ of the samples was extracted using $\mathrm{n}$-hexane in a Soxhlet extraction apparatus according to AOAC, (1990). Proximate composition was carried out on the defatted samples according to AOAC, (1990). 
Amino acid analysis was determined by the hydrolysis of the defatted samples using $6 \mathrm{M} \mathrm{HCl}$. The resulting sample solution was then analysed using Technicon sequential multisampling amino acid analyzer according to Olaofe et al., (2005)

\section{Results}

Table 1: Proximate Composition of Deffated Tectona grandis seed meal (\%)

\begin{tabular}{|l|l|l|l|l|l|l|}
\hline Parameter (\%) & Crude fat & Crude protein & CHO & Ash & Crude fibre & Moisture \\
\hline Composition & 1.00 & 42.0 & 41.5 & 7.00 & 3.30 & 5.20 \\
\hline
\end{tabular}

Table 2: Essential Amino Acid Composition of defatted Tectona grandis seed meal

\begin{tabular}{|l|c|}
\hline Essential Amino Acid & Amount $(\mathbf{g} / \mathbf{1 0 0 g})$ \\
\hline Histidine & 2.776 \\
Isoleucine & 3.047 \\
Leucine & 6.726 \\
Phenylalanine & 5.341 \\
Threonine & 3.078 \\
Tryptophan & 0.806 \\
Valine & 3.491 \\
Lysine & 2.654 \\
Methionine & 0.899 \\
TOTAL & 28.818 \\
\hline
\end{tabular}

Table 3: Non essential Amino Acid Composition of Tectona grandis seed meal

\begin{tabular}{|l|c|}
\hline Non essential Amino Acid & Amount (g/100g) \\
\hline Aspatate & 12.203 \\
Cystein & 1.120 \\
Glutamate & 23.626 \\
Arginine & 9.997 \\
Alanine & 4.596 \\
Glycine & 6.347 \\
Proline & 4.858 \\
Serine & 4.389 \\
Tyrosine & 2.391 \\
TOTAL & 69.527 \\
\hline
\end{tabular}

Table 4: Classification of Amino Acid content of Tectona grandis seed meal

\begin{tabular}{|l|l|}
\hline Amino acid composition & Amount $(\mathrm{g} / 100 \mathrm{~g})$ \\
\hline TAA & 98.35 \\
TNEAA & 69.57 \\
\%TNEAA & 70.70 \\
TEAA & 28.82 \\
\%TEAA & 29.30 \\
EA1AA & 13.27 \\
\%EAlAA & 13.49 \\
EArAA & 6.15 \\
\%EArAA & 6.25 \\
TNAA & 36.11 \\
\%TNAA & 36.72 \\
TAAA & 35.83 \\
\%TAAA & 36.43 \\
TBAA & 15.43 \\
\%TBAA & 15.69 \\
TSAA & 2.02 \\
\hline
\end{tabular}

TAA = Total amino acid, TNEAA = Total non essential amino acid, TEAA = Total essential amino acid, EAlAA = Essential aliphatic amino acid, EArAA = Essential aromatic amino acid, TNAA = Total neutral amino acid, TAAA = Total acidic amino acid, TBAA = Total basic amino acid, TSAA $=$ Total sulphur amino acid.

\section{Discussion}

Table 1 presents the results of proximate composition of the defatted seed flour. The results show that the seed meal is very low in moisture content. It has been reported that high moisture content enhances microbial growth and enzyme activity (Ogie et al., 2001). This implies that dried seed flour of Tectona grandis will not promote microbial growth and enzyme activity since its water content is low. The high protein content of Tectona grandis seed meal (42.0\%) showed that it has potential benefit as proteins are essential for the synthesis of body tissues and regulatory substances such as enzymes and hormones (Akindahunsi and Salawu, 2005). The fibre content is however very low with $3.30 \%$. High fibre content in food has been reported to cause 
intestinal irritation and lower nutrient bioavailability (Fagbohun et al., 2012). Apart from this, intake of fibre can stimulate weakening hunger, peristaltic movement and lower cholesterol level (Fagbohun et al., 2012) but low fibre content is not good for bowel function. The ash content $(7.00 \%)$ suggests the seed may likely contain useful nutritionally important mineral elements.

The seed meal is rich and a good source of carbohydrate (41.5\%) because it meets the Recommended Dietary Allowance (RDA) values e.g. children (40.0\%), adult (40.0\%), pregnant women (30.0\%) and lactating mothers (25.0\%) (Ishida et al., 2000) and is good as energy source. These also put the seed meal in advantage position to be equally used as animal feed. The value for crude fat in the seed meal was very low with $1.00 \%$.

Tables 2-4 present the results of essential amino acid composition, non essential amino acid composition and classification of amino acid composition of Tectona grandis respectively.

Chemical analysis of isolated protein identified 18 amino acids of which nine were essential and nine were nonessential. This is in disagreement with a similar investigation of Laskar et al., (1985) who identified 15 amino acids of which eight were essential and seven were non-essential. Leucine had the highest value of essential amino acid with a total $23.3 \%$ of the total value and closely followed by phenylalanine with $18.5 \%$ of the total essential amino acid. Since the seed meal is rich in these essential amino acids, it could probably be a source for both livestock and human beings while the others not available enough could be supplemented. Methionine and tryptophan had the lowest amount of essential amino acid with 0.899 and $0.806 \mathrm{~g} / 100 \mathrm{~g}$ representing 3.11 and $2.80 \%$ of the total essential amino acids respectively but these could not be detected by Laskar et al., (1985). Since the samples were taken from different locations far away from each other, different climatic or environmental conditions could have been responsible for the difference. The defatted seed meal is very rich in glutamic acid which had about $34.0 \%$ of the total non-essential amino acid and closely followed by aspartic acid which had $17.6 \%$ of the total non-essential amino acid and this is about half of the amount of glutamic acid. This showed that both the glutamic and aspartic acids were the major amino acids in the defatted meal of Tectona grandis. This observation is in close agreement with the reports of Oyewusi et al., (2007), Olaofe and Akintayo, (2000) and Adeyeye and Afolabi, (2004) who had earlier observed that aspartic and glutamic acids were always the most abundant in some seed meals.

The percentages of essential, non-essential, acidic, basic, neutral, aliphatic and aromatic amino acids are $29.3,70.7,36.4,15.7,36.7,6.15$ and $36.7 \%$ respectively. The total acidic amino acids were found to be greater than the basic amino acid, which implied that the total protein would probably be acidic in nature. The percentage essential aliphatic amino acid is higher than essential aromatic amino acid which implied that the seed meal could probably be aliphatic. This indicates that the sample could probably have better emulsification properties (Oyewusi et al., 2007 and Olaofe et al., 2005).

\section{References}

[1]. Aboaba, S; Akinsola, A and Flamini, G. (2013): Chemical constituents, toxicity and antimicrobial activities of the essential oil from the leaves if Tectona grandis. Elixir Bio Technology, 61, pp 16759-16789.

[2]. Adeyeye, E.I and Afolabi, F.O. (2004): Amino acid composition of three different types of land snails consumed in Nigeria. Food Chem., 85: pp 95-97.

[3]. Akindahunsi, A.A. and Salawu, S.O. (2005): Phytochemical screening and nutrient- antinutrient composition of selected tropical green vegetables. African Journal of Biotechnology. 4: 497-501.

[4]. Fagbohun, E.D., Egbebi, A.O. and Lawal, O.U. (2012): Phytochemical screening, proximate analysis and in-vitro antimicrobial activities of methanolic extract of Cnidoscolus aconitifolius leaves. International Journal of Pharmaceutical Sciences Review and Research; 13 (1): pp 28-33.

[5]. Francisco A. M, Rodney L, Rosa M. V, Clara N. and Jose M. G. M.(2008): Bioactive apocarotenoids from Tectona grandis, Phytochem. 69: 2708-2715.

[6]. Goel, R.K; Pathak, N.K; Biswas, M.; Pandey, V.B. and Sanyal, A.K. (1987): Effect of lapachol, a naphthaquinone isolated from Tectona grandis on peptic ulcer and gastric secretion. Journal of Pharm. Pharmacol. 39 (2): pp 138-140.

[7]. Goswami, D.V. Patil, M.J. Modi, A.and. Tiwari, R (2010): Pharmacognostic and Phytochemical Investigation of Stem Bark of Tectona grandis Linn. International Journal of Pharma and Bio Sciences V1 (2): pp 2215-2220.

[8]. Guptha, P.K and Singh, P.A. (2004): Napthoquinone derivative from Tectona grandis. Journal of Asian Nat. Prod. Res., 6 (3): pp 237-240

[9]. Ishida, H.H; Suzuno, N; Sugiyayama, S; Innami, T; Todokoro, T. and Maekawa, A. (2000): Nutritional and evaluation of chemical component of leaves, stalks and stems of sweet potatoes (Ipomoea batataspoir). Food Chem. 68: pp 359-367.

[10]. Jaybhaye, D; Varma, S; Gagne, N; Bonde, V. Gite, A. and Bhosie, D. (2010): Effects of Tectona grandis seeds on hair growth activity of albino mice. International Journal of Ayurvera Res: 1 (4): 211-215.

[11]. Khera C. P. (2007): Indian Medicinal Plants: An Illustrated Dictionary. Springer Verlag. Heidelberg; pp. 649.

[12]. Khera, N and Bhargava, S. (2013): Phytochemical and pharmacological evaluation of Tectona grandis. International Journal of Pharmacy and Pharmaceutical Sciences; 5 (3): pp 923-927.

[13]. Laskar, S; Majumdar, S.G. and Basak, B. (1985): Isolation and chemical investigation of Tectona grandis seed protein. Journal of American oil chemists Society, 62 (8), pp 1266-1268.

[14]. Nayeem, N. and Karvekar, M.D. (2010): Analgesic and anti-inflammatory activity of the methanolic extract of frontal leaves of Tectona grandis. Internet Journal of Pharmacology, 8: pp 1531-2976.

[15]. Ogie, B.M; Ha-thi, A.D; Mulokozi, G. and Hambraeus, L. (2001): Micronutrient composition and nutritional importance of gathered vegetables in Vietnam. International Journal of Food Science Nutrition; 52: pp 485-499.

[16]. Olaofe, O; Faleye, F.J. and Adebiyi, A.S. (2005): Amino acid composition of variegated grasshopper Zenocerus variegates L. and infrared characterization of its oils. Int. Journal of Chem. 15 (1): pp 43-48. 
[17]. Olaofe, O. and Akintayo, E.T. (2000): Prediction of isoelectric points of legumes and oil seed proteins from their amino acid composition. Journ. of Technoscience, 4: pp 44-48.

[18]. Oyewusi, P.A; Akintayo, E.T. and Olaofe, O. (2007): The proximate and amino acid composition of defatted rubber seed meal. Journ. of Agric. \& Environ., 5 (3 \& 4): pp 115-118.

[19]. Rodney Lacret, Rosa M. Varela, Jose' M.G. Molinillo, Clara Nogueiras and Francisco A. Macı'as (2012): Tectonoelins, new norlignans from a bioactive extract of Tectona grandis, Phytochem Lett ; 5: pp 382-386.

[20]. Singh J.; Bhuyan T. C. and Ahmed A. (1996).: Enthnobotanical studies on the Mishing tribes of Assam with special reference to food and medicinal plants. J Econ Taxon Bot Additional series; 12: pp 350-356.

[21]. Shruthi, D.P; Sunith, K.E; Haritha, K.E; Govindappa, M. and Siddalingeshwara, K.G. (2012): Phytochemical screening, antioxidant and anti-inflammatory activity of different extracts from leaf, stem and back of Tectona grandis. International Journal of Research in Pharmacology and Pharmacotherapeutics, 12, pp 140-146.

[22]. Sumthong P, Damveld R. A, Choi Y. H, Arentshorst M, Ram A. F, Vanden Hondel C. A. and Verpoort R (2006): Activity of quinines from teak (Tectona grandis) on fungal wall stress. Planta Medica; 72(10): 943-944. 